\title{
IAMJ
}

INTERNATIONAL

AYURVEDIC

MEDICAL JOURNAL

\section{ROLE OF VIRECHANA IN THE EFFECTIVE MANAGEMENT OF DIABETES MELLITUS W.S.R. TO PRAMEHA - A CASE STUDY}

\section{Vaishnavi Joshi $^{1}$, Rajendra Huparikar ${ }^{2}$}

$13^{\text {rd }}$ Year PG Scholar, ${ }^{2}$ Guide

Department of Panchakarma

Tilak Ayurved Mahavidyalay, Pune, Maharashtra, India

Corresponding Author: drjo1995@gmail.com

\section{https://doi.org/10.46607/iamj2609062021}

(Published Online: June 2021)

Open Access

(C) International Ayurvedic Medical Journal, India 2021

Article Received: 30/05/2021 - Peer Reviewed: 10/06/2021 - Accepted for Publication: 11/06/2021

\section{Check for updates}

\section{ABSTRACT}

Diabetes Mellitus refers to a group of common metabolic disorders that share the phenotype of hyperglycemias. Depending upon factors contributing to hyperglycemia include reduced insulin secretion, glucose utilization and increased glucose production. Diabetes mellitus is now become most common among all diseases in the present era. In India, this is increasing rapidly and seems that India is going to be capital of Diabetes Mellitus in next coming years. According to Ayurvedic texts, Acharya Charaka has explained about Prameha which can be compared with Diabetes Mellitus. The main symptom of Prameha is 'Prabhuta Aavila Mutrata. Tridosha dushti in Prameha progressively leads to affect Rasa, Meda, Shukra, Ambu, Lasika, Majja and Oja. All these affected Dosha and Dushya influence Basti and manifest the symptom like 'Prabhuta Avila Mutrata'. Virechana was given in this case because Acharya Charak has mentioned dushti of Kapha, Pitta and Vata is present in Prameha. Phalashruti of Virechana says that there is elimination of Dosha in the sequence of Vit (mala), Pitta, Kapha, Anil. Hence role of Virechana is important in the Chikitsa of Prameha.

Keywords: Diabetes Mellitus, Prameha, Samshodhan, Virechan. 


\section{INTRODUCTION}

Diabetes mellitus can be produced by decreased insulin secretion decreased glucose utilization. Diabetes mellitus literally means to insufficiency of insulin. It is produced by beta cells of pancreatic islets of pancreas. Glucose is the key regulator of insulin secretion by pancreatic beta cells although amino acids, ketones, various nutrients, gastrointestinal peptides and transmitters also influence insulin secretion. Pancreas situated at the junction of Amashaya and Pakvashaya i.e. Pittadhara kala.

Pittadhara kala is nothing but the Grahani. Hence in the Samprapti of Prameha mainly affected organ is Grahani. Virechana is the purifactory procedure especially for Paittika diseases. It is also useful in disorders in which Pitta is affected with Vata and Kapha dosha. (Cha.su.25/40, AH.su1/25). To evacuate morbid Doshas by targeting the Mulasthana of Pitta and Ashay of Pitta is quite effective. Hence, administration of Virechana karma in management of Prameha is thoughtful because of its simplicity, eliminating the Dosha in more quantity and less stress.

\section{CHIEF COMPLAINTS}

Weight gain, frequency and urgency urination (10-12 times/day), tingling sensation over both feet, feeling of heaviness in whole body, fatigue, joint pain, morning stiffness of all joints, excessive sweating, all above symptoms since 6 months.

\section{H/O OF PRESENT ILLNESS}

A male patient aged about $30 \mathrm{yr}$. C/o weight gain, frequency and urgency urination (10-12 times/day), tingling sensation over both feet, heaviness in whole body, fatigue, all joints pain, morning stiffness of all joints, excessive sweating all symptoms about since 6 months. Hence for further management he came to hospital.

\section{CRONOLOGY OF SYMPTOMS}

- He was working as a surgeon, having habits vizly alcohol, non-vegetarian food, untimely food.

- There was no history of Diabetes Mellitus on the maternal and paternal side.

- When he suffered above symptoms, his RBS was found to be $214 \mathrm{mg} / \mathrm{dl}$. His fasting blood sugar level was $146.9 \mathrm{mg} / \mathrm{dl}$ and post prandial blood sugar level was $200 \mathrm{mg} / \mathrm{dl}$.

- His HbA1c was found to be 8.0

- The range of RBS was found to be in between 140 $\mathrm{mg} / \mathrm{dl}$ to $300 \mathrm{mg} / \mathrm{dl}$ till the date before starting treatment.

- He followed diabetic diet, however no depletion in symptoms were observed even after six months.

\section{ETIOLOGY AND AYURVEDIC PARALANCE}

Spicy food, junk food (ch.chi.29/5)

Irregular food habits, having street food, stale food. Irregular bowel habits, (Ch.Chi.15/4)

Day time sleep, excessive sleep, excessive curd consumption,

Consumption of excessive milk products.

(Ch.Chi.6/4)

\section{SYMPTAMATOLOGY AND AYURVEDIC PARLANCE}

Patient was in the state of Bahudoshavastha. He had developed complaints like Avipaka, Aruchi, Sthaulya, Panduta, Gaurava, Klama, Kandu, Aalasya, Shram, Dourbalya, Daurgandhya, Shleshmapittotklesha, Atinidrata.

(Ch.Su.16/13-16)

Excessive sweating, fatigue, lethargy.

Slumber time in day.

Tingling sensation on both feet.

Weight gain.

Frequency and urgency of urination (10-12 times/day) Heaviness in whole body. (Ch.Chi.6/13,14) 


\section{VARIOUS CAUSES OF PITTA AND KAPHA PRAKOPA IN THIS PATIENT}

Bakery products, fruit juices, irregular time of food consumption, sleeping habitat daytime, stress, unhygiene.

\section{SAMPRAPTI}

\section{Hetusevan}

Consumption of food containing Guru, Snigdha, Amla, Lavanan,

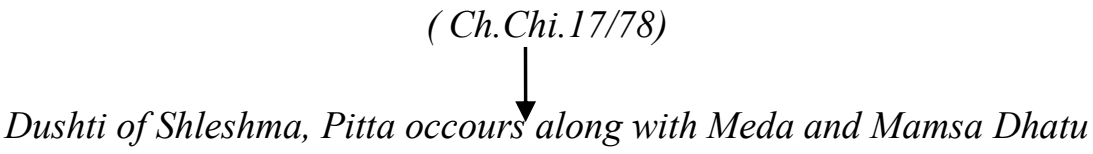

Due to above mentioned causes, covering of Vayu occurs and further

affects Basti

(Ch.Su.17/80)

Affected Meda, Mamsa, Kleda, Kapha gets situated in
(Ch.Chi.6/5,
Leading to Prameha

\section{TREATMENT}

1. Samshodhan and Langhan in Kapha Pradhan Prameha

Virechan in Pitta Pradhan Prameha. (Ch.Chi.6/25)

2. Elimination of Dosha from the nearest route. (Ch.Su.16/13-16)

Table 1: Virechana was planned on these lines with the following mode of treatment.

MODE OF TREATMENT

Rukshana,Deepana,Pachana

Abhyanga

Shashtik shali pinda sweda

Sneha pana

Virechana, Virechanopag

Peyadi sansarjan krama

\section{MODE OF ACTION OF VIRECHANA}

There is predominance of Prithvi and Jala Mahabhuta in Virehana Dravya. Both of above have natural tendency to move downwards and hence they can assist in induction of Virechana. Drugs capable of inducing Virechana possesses Ushna, Tikshna, Sukshma, Vyavayi, Vikasi properties. The Ushna property may assist in increasing the quantum of Agni. It can cause Vishyandana i.e. oozing of the Dosha in the Koshtha from where they can be readily expelled out. Due to Tikshna property, drug is able to disintegrate the Sanghata of dosha. Due to Vyavayi property, such a

\section{USED DRUGS}

Mustadi kwatha (cha.u.23/12,13)

Dhanwantara taila

Bala pottali

Dhanwantara Gruta (A.H.chi.12/20-24)

Trivrittta avaleha 50 grms, Aargvadh, Mrudvika phant

Madhyam suddhi sansarjana karma

medicine is able to spread in the whole body prior to its elimination.

Virechan drug possessing above properties reaches the Hridaya by virtue of its Veerya and then following the Dhamani it pervades the whole body through Sthoola and Sukshma Strotas. As Snehana and Swedana are performed prior to Virechana, in a Snigdha body Dosha smear easily without any obstacle and comes easily to Pakvashya from where Virechana evacuates them. In the above process the association of Hridaya can be understood in two ways. Hridaya can be taken as centre of local nerve plexus upon which the drug 
may act. The meaning of word Hridaya in sense of some centre of brain or nerve plexus of abdomen can be well understood in the context of mode of action of Ghreya yoga of Virechana. Virechana is the best treatment of Pitta vikara and also Kapha situated in Pitta sthana. Here Mulasthana of Pitta is Grahani hence to purify Grahani, Virechana is the best choice. According to Charakacharya poorvaroopa of Prameha occurs due to Meda, Majja, Rasa, Rakta dushti. Acharya kashyapa mentioned that Shuddhi of Sapta Dhatu takes place by Virechana karma. It removes Avaran (cover) of Kapha and Vata and improves
Meda Dhatwagni. Ultimately Kleda and Meda vrudhi decreases. Mutravaha, Medovaha, Udakvaha strotoshuddhi is possible due to Virechana. The most important thing is Prameha occurs as Santarpan janya vyadhi. Any kind of Shodhan is required for these Santarpan janya Vyadhis. Virechana is mentioned in the chikitsa of santarpan janya Vyadhi. It flushes out all unwanted Ambu, Sweda, Kleda, Meda from body. And hence according to Charakacharya Virechana is most effective treatment in the Prameha Vyadhi (Diabetes mellitus).

Table 2: RESULTS

\begin{tabular}{|l|l|}
\hline Before treatment & After treatment \\
\hline Weight $-82 \mathrm{~kg}$ & Weight $-72 \mathrm{~kg}$ \\
\hline Range of GRBS $140-300 \mathrm{mg} / \mathrm{dl}$ & Range of GRBS $110-170 \mathrm{mg} / \mathrm{dl}$ \\
\hline $\mathrm{HbAlc}-8.0 \%$ & HbA1c $-6.8 \%$ \\
\hline FBGS $-146 \mathrm{mg} / \mathrm{dl}$ & FBGS-110mg/dl \\
\hline Post prandial $-200 \mathrm{mg} / \mathrm{dl}$ & Post prandial- $124.1 \mathrm{mg} / \mathrm{dl}$ \\
\hline Frequency urination -10 to 12 times $/$ day & Frequency of urination -6 to 7 times $/$ day \\
\hline Fatigue, joint pain, heaviness,tingling sensation over both feet & Reduction in all symptoms is markeble. \\
\hline
\end{tabular}

\section{DISCUSSION}

Virechana karma removes Bahudrava Shleshma, excessive Ambu, Kleda which all leads to Prameha one can achieve Dosha-Dhatu equilibrium in Prameha with the help of Virechana. In Prameha there is mainly Dhatwagnimandya, to conquer this Agnimandya treatment of Pitta is very important. Due its Ushan, Tiksha, Vyavayi, Vikasi, Sukshma, Laghu properties the evacuation of all morbid Doshas from Shukshma Strotas and Agnivruddhi can be achieved. Properties of Kleda, Meda, Rasa, Ambu, Majja which mainly get affected in Prameha are exactly opposite to properties of Virechana dravya. Hence one can achieve the goal of treating the Prameha successfully.

\section{CONCLUSION}

In this case, here are three key points that are to be studied. The treatment principle that is used in this case, role of drugs which has used in this treatment protocol. While going through principle of treatment Acharya Charak has mentioned that when there is
Vruddhi of Kapha, Kleda, Meda, Vaidya has to focus on Kpha Pitta Dosha. Due to Ushan, Tiksha, Vyavayi, Vikasi guna of Virechak dravya morbid doshas like Kleda, Meda, Kapha can be eliminated. By applying principle of Samanya Vishesh Siddhant. Trivutta is Kashay rasatmaka, Katu Vipaki and having properties like Ruksha, Kaphapitta Prashamani, Sarvarogahra. Hence again by applying principle of Rhasa of morbid Dosha can be achieved by using Vishesh (opposite properties) Gunatmak Dravya. Hence Trivrutta Avleha is used in this patient.

\section{REFERENCES}

1. Harrison's principles of internal medicines, edited by Anthony S Fauci, Eugene Brauwald, Dennis L Kasper, Stephen L Hauser, DanL Longo, J. Larry Jameson, Joseph Loscalzo reprint 17 th edition, chapter fig 338-14, P- 2299

2. Yadavaji Trikamaji Acharya, Charak Samhita of Agnivesha revised by Charak and Dhrudhbala with Ayurved Dipika Commentary by Chakrapani Datta, 
Choukhambha surabharati prakashan, Varanasi,2016, Chikitsa Sthana, chapter 29, shloka 5, p 627.

3. Yadavaji Trikamaji Acharya, Charak Samhita of Agnivesha revised by Charak and Dhrudhbala with Ayurved Dipika Commentary by Chakrapani Datta, Choukhambha surabharati prakashan, Varanasi,2016, Chikitsa Sthana, chapter 15, shloka 42, p 517.

4. Yadavaji Trikamaji Acharya, Charak Samhita of $A g$ nivesha revised by Charak and Dhrudhbala with Ayurved Dipika Commentary by Chakrapani Datta, Choukhambha surabharati prakashan, Varanasi,2016, Chikitsa Sthana,chapter 6,shloka 4, p 445.

5. Yadavaji Trikamaji Acharya, Charak Samhita of Agnivesha revised by Charak and Dhrudhbala with Ayurved Dipika Commentary by Chakrapani Datta, Choukhambha surabharati prakashan, Varanasi,2016, chikitsa sthana, chapter 6, shloka 13,14, p 446.

6. Yadavaji Trikamaji Acharya, Charak Samhita of Agnivesha revised by Charak and Dhrudhbala with Ayurved Dipika Commentary by Chakrapani Datta, Choukhambha surabharati prakashan, Varanasi,2016, Chikitsa Sthana, chapter 17, shloka 78, p 103.

7. Yadavaji Trikamaji Acharya, Charak Samhita of Agnivesha revised by Charak and Dhrudhbala with Ayurved Dipika Commentary by Chakrapani Datta, Choukhambha surabharati prakashan, Varanasi,2016, Sutra Sthana,chapter 17,shloka 80, p 103.

8. Yadavaji Trikamaji Acharya, Charak Samhita of $A g$ nivesha revised by Charak and Dhrudhbala with Ayurved Dipika Commentary by Chakrapani Datta, Choukhambha surabharati prakashan, Varanasi,2016, Chikitsa Sthana, chapter 6, shloka 5, p 445.

9. Yadavaji Trikamaji Acharya, Charak Samhita of $A g$ nivesha revised by Charak and Dhrudhbala with Ayurved Dipika Commentary by Chakrapani Datta, Choukhambha surabharati prakashan, Varanasi, 2016, Chikitsa Sthana, chapter 6, shloka 6, p 445.

10. Yadavaji Trikamaji Acharya, Charak Samhita of Agnivesha revised by Charak and Dhrudhbala with Ayurved Dipika Commentary by Chakrapani Datta, Choukhambha surabharati prakashan, Varanasi, 2016, Chikitsa Sthana, chapter 6, shloka 25, p 447.

\section{Source of Support: Nil \\ Conflict of Interest: None Declared}

How to cite this URL: Dr.Vaishnavi Joshi \&, Dr. Rajendra Huparikar: Role Of Virechana In The Effective Management Of Diabetes Mellitus W.S.R. To Prameha - A Case Study. International Ayurvedic Medical Journal \{online\} 2021 \{cited June, 2021\} Available from: http://www.iamj.in/posts/images/upload/1307 1311.pdf 